\title{
Analisis Framing Model Robert Entman Tentang Pemberitaan Kasus Korupsi Bansos Juliari Batubara Di Kompas.Com Dan BBC Indonesia.Com
}

\author{
Intan Leliana ${ }^{1}$, Herry $^{2}$, Panji Suratriadi ${ }^{3}$, Edward Enrieco $^{4}$ \\ ${ }^{1}$ Universitas Bina Sarana Informatika \\ intan.ila@bsi.ac.id \\ ${ }^{2}$ Universitas Bina Sarana Informatika \\ herry.hhe@bsi.ac.id \\ ${ }^{3}$ Universitas Bina Sarana Informatika \\ panji.pti@bsi.ac.id \\ ${ }^{4}$ Universitas Bina Sarana Informatika \\ edward.edc@bsi.ac.id
}

\begin{abstract}
Cara Sitasi: Intan L, Herry, Panji S, Edward E (2021) Analisis Framing Model Robert Entman Tentang Pemberitaan Kasus Korupsi Bansos Juliari Batubara Di Kompas.Com Dan BBC Indonesia.Com, 2021 21(1), 60-67 Retrieved fromhttps://doi.org/10.31294/jc.v19i2
\end{abstract}

\begin{abstract}
Corruption is a pervasive global problem with detrimental effects on economic performance, political stability and community integration. Corruption has provided its own moment for the mass media which includes electronic mass media and printed mass media today to be used as the latest news which is called the Headline (headline). One of the news that discusses the new corruption case is the case of Social Assistance Funds (Bansos) at the Ministry of Social Affairs. The Corruption Eradication Commission (KPK) which has appointed the Minister of Social Affairs (Mensos) Juliari Batubara as a suspect in the corruption of social assistance (Bansos) for residents affected by the Covid 19 pandemic. The method in this study uses a qualitative description which aims to describe systematically, factually, and accurately about news on the corruption case of Social Affairs Minister for Social Affairs Juliari Batubara in Kompas.Com and BBCIndonesia.com with framing Robert Entman analysis. The results of this study are based on the results of the framing analysis in this study, it is very clear that the role of the media is not limited to conveying information, the times demand the media to play the role of 'watch dog' or guard dog and control for the government and related institutions in formulating every policy. for the benefit of society. The results of the study show that the media Kompas.com and BBCIndonesia.com provide space for information and clarification for the government and the KPK to make all efforts to curb and overcome the problem of corruption in covid 19 social assistance funds.
\end{abstract}

Keywords: Corruption, Framing, Bansos

\section{PENDAHULUAN}

Media massa merupakan hal yang tidak bisa lepas dari kegiatan manusia dalam mencari sebuah berita. Berita adalah informasi terbaru yang dapat datang dari arah mana saja (Ibrahim, 2007). Informasi sudah menjadi kebutuhan manusia, sehingga media massa memiliki peran yang strategis dalam memberikan informasi secara serempak kepada publik. Dalam menyampaikan informasi kepada publik, media massa menyampaikan berita baik melalui media cetak dan juga media elektronik.
Informasi yang ditampilkan oleh media, pasti memiliki tujuan, baik itu tujuan komersial, ideologi, ataupun politik. Untuk meraih suatu tujuan itu media membingkai berita dengan mempengaruhi pikiran pembaca sehingga terbentuk opini pembaca sesuai dengan yang diharapkan oleh media tersebut, atau dapat disebut dengan istilah framing. Menurut Robert N, Entman Teori framing adalah penonjolan aspek-aspek tertentu didalam sebuah berita, penonjolan aspek tertentu maksudnya membuang sebagian cerita dengan menonjolkan cerita tertentu. Maka sebuah media dalam memberikan informasi 
kepada publik, media dapat mengembangkan sebuah peristiwa atau kasus-kasus yang dianggap dapat membuat publik terpengaruh dengan isu yang disampaikan. Maka framing disini berperan untuk membingkai sebuah informasi agar informasi yang disampaikan sesuai dengan kepentingan media (Wijanarko, 2014).

Munculnya kasus kasus korupsi di Indonesia memiliki dampak yang sangat serius terhadap masyarakat. Korupsi adalah masalah global yang meresap dengan efek merugikan pada kinerja ekonomi, stabilitas politik, dan integrasi masyarakat (Sovianti, 2019). Korupsi telah memberikan momen tersendiri bagi media massa yang meliputi media massa elektronik dan media massa cetak saat ini untuk dijadikan berita-berita terkini yang disebut dengan Headline (berita utama). Melalui proses tersebut, maka isu-isu yang dimunculkan oleh media dalam melihat suatu peristiwa tidak lepas dari perspektif yang dibangun dalam membuat berita, begitu pula dalam pemberitaan tentang kasus tersebut.

Media dalam memaknai isu suatu kasus tentunya memiliki persepsi dan pemaknaan yang berbeda-beda. Sehingga perspektif dalam menulis berita, mulai dari sudut berita, pemaknaan suatu kasus, gaya penulisan berita yang berbeda, kategorisasi, serta terdapat unsur-unsur tersendiri yang terkandung didalam penulisan berita sesuai dengan isu-isu yang akan dimunculkan. Berita yang akan disampaikan kepada khalayak tentunya ada kebijakan yang ditentukan oleh keredaksian yang dapat membatasi kebebasan wartawan dalam menulis berita. Kebijakan redaksional tersebut menjadi pedoman dalam menentukan kejadian macam apa yang oleh surat kabar itu patut diangkat serta dipilih untuk menjadi berita maupun bahan komentar. Visi pokok yang dijabarkan menjadi kebijakan redaksional tersebut untuk dijadikan kerangka serta acuan kriteria dalam menyeleksi dan mengolah menjadi berita (Octama, 2001).

Adapun salah satu berita yang membahas tentang kasus korupsi baru baru ini adalah kasus dana bantuan Sosial (Bansos) di Kementerian Sosial. Komisi Pemberantas Korupsi (KPK) yang telah menetapkan Menteri Sosial (Mensos) Juliari Batubara sebagai tersangka korupsi bantuan sosial (Bansos) bagi warga yang terdampak pandemic Corona. Juliari yang datang dari Partai Demokrasi Indonesia Perjuangan (PDIP) itu dilaporkan menerima suap sebesar Rp 17 miliar dari penunjukan rekanan pengadaan sembako Bansos sembako untuk warga Jabodetabek. Bansos itu sendiri nilainya Rp 600.000 per bulan, yang dibagikan dalam dua paket senilai Rp 300.000 per dua minggu.

Pertimbangan peneliti, bahwa dalam kasus korupsi Bansos ini adalah ditengah situasi wabah yang banyak membuat keprihatinan masyarakat dunia, terlebih Indonesia. Dengan adanya korupsi yang terjadi atas bantuan sosial dalam rangka penanggulangan Covid 19, membuat masyarakat prihatin masih ada pejabat pemerintah yang tega mengambil kesempatan untuk mencuri uang negara. Peneliti menggunakan media daring dengan pertimbangannya adalah media daring dapat menyimpan berbagai berita dan dapat diakses oleh pembaca dengan cepat, dan sesegera mungkin sehingga pembaca dapat langsung mengetahui informasi. Peneliti memilih media daring Detik.com dan Kompas.com sebagai objek dari pemberitaan tentang kasus Korupsi bansos Corona ini.

\section{Media massa}

Menurut (Anwar, 2011) media massa menyampaikan pesan yang aneka ragam dan actual tentang lingkungan social dan politik. Surat kabar dapat menjadi medium untuk mengetahui berbagai peristiwa politik yang aktual yang terjadi di seluruh penjuru dunia. Radio dan televisi sebagai media massa elektronik juga menyampaikan berbagai kejadian dan berita yang dibutuhkan oleh masyarakat

\section{Analisis Framing}

Menurut Erianto dalam (Yeni, Selviera, Chelsy, 2018) Framing didefinisikan sebagai proses membuat suatu pesan lebih menonjol dan melihat bagaimana media mengkronstruksi realitas. Analisis Framing juga dipakai untuk melihat bagaimana peristiwa dipahami dan dibingkai oleh media. Dalam perpektif komunikasi, analisis framing dapat dipakai untuk membedah caracara atau ideologi mencermati strategi seleksi, penonjolan dan pertautan fakta dalam berita agar lebih bermakna, lebih menarik, lebih berarti atau lebih diingat, untuk menggiring interpretasi khalayak sesuai perspektif nya.

Analisis framing secara sederhana dapat digambarkan sebagai analisis untuk mengetahui bagaimana realitas (peristiwa, aktor, kelompok, atau apa saja) dibingkai oleh media. Pembingkaian tersebut melalui proses konstruksi. Di dalam analisis framing, realitas social dimaknai dan dikonstruksi dengan makna tertentu. Peristiwa dipahami dengan bentukan tertentu. Semua elemen tersebut tidak hanya bagian dari teknik jurnalistik, tetapi menandakan bagaimana peristiwa dimaknai dan ditampilkan (Eriyanto, 2011). Dalam analisis framing, yang dilakukan pertama kali adalah melihat bagaimana media mengkonstruksi realitas. Wartawan dan media yang yang secara aktif membentuk realitas. Lebih spesifik, bagaimana media membingkai peristiwa dalam konstruksi tertentu, sehingga yang menjadi titik perhatian bukan apakah media memberitakan negative atau positif, melainkan bagaimana bingkai yang dikembangkan oleh media.

Entman melihat framing dalam dua dimensi besar: seleksi isu dan penekanan atau penonjolan aspek-aspek tertentu dari realitas/isu. Penonjolan adalah proses membuat informasi menjadi lebih 
bermakna, lebih menarik, berarti atau lebih diingat oleh khalayak (Entman, 2007). Framing adalah pendekatan untuk mengetahui bagaimana perspektif atau cara pandang yang digunakan oleh wartawan ketika menyeleksi isu dan menulis berita. Cara pandang atau perspektif itu pada akhirnya menentukan fakta apa yang diambil, bagian mana yang ditonjolkan dan dihilangkan, dan hendak dibawa ke mana berita tersebut.

Teks dapat membuat sedikit informasi lebih menonjol dengan penempatan atau pengulangan, atau dengan mengaitkannya dengan simbol budaya yang akrab. Namun, bahkan satu tampilan gagasan yang tidak bergejolak di bagian teks yang tidak jelas bisa sangat menonjol, jika itu sesuai dengan skema yang ada dalam sistem kepercayaan penerima. Dengan cara yang sama, sebuah ide yang ditekankan dalam sebuah teks dapat menjadi sulit bagi penerima untuk memperhatikan, menafsirkan, atau mengingat karena skema mereka yang ada. Untuk tujuan kita, skema dan konsep yang terkait erat seperti kategori, skrip, atau stereotip mengandung kluster ide yang tersimpan secara permanen yang memandu pemrosesan informasi individu. (Entman, 2007). Penonjolan adalah produk dari interaksi teks dan penerima, kehadiran frame dalam teks, seperti yang dideteksi oleh peneliti, tidak menjamin pengaruh mereka dalam pemikiran audiens. (Entman, 2007)

Teori yang digunakan pada penelitian ini adalah teori konstruksi media massa yang dikemukakan oleh Berger dan Luckman. Teori ini memiliki beberapa asumsi dasar, yaitu: realitas yang ada diciptakan oleh manusia melalui kekuatan mengkonstruksi pada dunia sekitarnya, adanya hubungan antara pemikiran manusia dan konteks sosial yang berkembang dan dilembagakan, kehidupan masyarakat akan terus menerus dikonstruksi dan realitas merupakan kualitas di kenyataan masyarakat yang ada dan tidak bergantung pada seseorang. Terdapat tiga hal yang dapat dianalisa dengan teori konstruksi media massa yaitu informasi yang sifatnya menyentuh banyak orang seperti persoalan yang sensitif, mengandung unsur sensualitas dan kengerian. Hal yang sensitif merupakan persoalan yang sensitif yang meresahkan di masyarakat (Puji, 2016).

Penelitian ini merupakan penelitian deksriptif kualitatif dengan metode analisis framing model Entman (Entman, 2007). Gitlin menyatakan bahwa framing merupakan strategi membentuk dan menyederhanakan realitas, dengan cara menyeleksi, mengulangi dan menekankan aspek tertentu sehingga suatu peristiwa atau isu lebih menyita perhatian pembacanya. (Eriyanto, 2008). Model framing Entman memiliki empat kategorisasi elemen yaitu: Define problems, Diagnose causes, Make moral judgement dan Treatment recommendation (Malik, 2019).

Define Problems merupakan tahapan dalam framing yang digunakan untuk menekankan bagaimana peristiwa dipahami oleh wartawan ketika muncul suatu permasalahan. Diagnose causes, sebuah tahapan analisis yang dilakukan untuk membingkai siapa yang dianggap sebagai aktor utama suatu peristiwa. Make moral judgment merupakan elemen framing yang digunakan untuk membenarkan argumentasi pada pendefinisian masalah yang sudah dibuat. Treatment recommendation digunakan untuk menilai solusi apa yang dipilih untuk menyelesaikan masalah. Penyelesaian tersebut sangat tergantung pada bagaimana peristiwa itu dilihat dan siapa yang dipandang sebagai penyebab masalah (Elvras Jaya, 2019).

\section{METODE PENELITIAN}

Menurut (Sugiyono, 2017) metodologi penelitian adalah "Metode Penelitian diartikan sebagai cara ilmiah untuk mendapatkan data dengan tujuan dan kegunaan tertentu".

Adapun sifat penelitian ini adalah deskriptif kualitatif yang bertujuan untuk mendeskripsikan secara sistematis, factual, dan akurat tentang pemberitaan kasus korupsi Bansos Mensos Juliari Batubara di Media Online Kompas.Com dan BBCIndonesia.com. Berdasarkan rumusan masalah peneliti, yang menjadi unit. analisis dalam penelitian ini adalah teks yang terdapat di dalam pemberitaan mengenai kasus korupsi Bansos Mensos Juliari Batubara pada Media Online Kompas.Com dan BBCIndonesia.com

Peneliti menggunakan sumber data yang berasal dari berita-berita di Kompas.Com dan BBCIndonesia.com. Untuk penelitian ini peneliti mengambil berita mengenai Mensos Juliari Batubara ditetapkan sebagai tersangka dan penangkapan Mensos Juliari Batubara oleh KPK.

Menurut (Kriyantono, 2016) menjelaskan, "Sebagian dari keseluruhan objek atau fenomena yang akan diamati inilah yang disebut sampel. Sedangkan keseluruhan objek atau fenomena yang diriset disebut populasi."

Peneliti memilih objek penelitian mengenai penetapan dan penangkapan Juliari Batubara karena media meliput berita tersebut secara terus-menerus. Berita penetapan Juliari Batubara sebagai tersangka pada hari Minggu 6 Desember 2020.

Data penelitian diperoleh dari berbagai pemberitaan yang muncul di portal berita Media Online Kompas.Com dan BBCIndonesia.com. Data primer penelitian mengenai pemberitaan Penangkapan Mensos Juliari batubara dalam korupsi Bansos covid 19. Data sekunder penelitian berkaitan dengan berbagai literatur yang dapat dijadikan 
sebagai rujukan dalam proses analisis pemberitaan baik dari sisi media maupun realitas yang diteliti.

Penelitian ini berupaya menggali proses pembingkaian media online dalam pemberitaan kebijakan penangan Covid-19 dan peran generasi milenial berdasarkan empat elemen analisis framing model Entman. Penelitian ini dilakukan untuk melihat bagaimana media online mempersepsikan kinerja gugus tugas covid-19, menggali aktor utama yang ditonjolkan dalam proses pemberitaan, penggunaan argumentasi yang digunakan dalam memperkuat pemberitaan dan menemukan solusi yang ditawarkan dalam upaya menyelesaikan permasalahan. Melalui keempat elemen analisis framing ini dapat menunjukkan keutuhan pembingkaian pemberitaan mengenai Penangkapan Mensos Juliari batubara dalam korupsi Bansos covid 19.

Kasus korupsi Bansos Mensos Juliari Batubara diliput secara berbeda pada setiap media massa. Hal ini disebabkan Kasus korupsi Bansos Mensos Juliari Batubara dipahami dan dibangun berbeda oleh masing-masing media. Analisis framing memiliki dua konsep utama, yaitu:

1) Bagaimana peristiwa diartikan. Itu berhubungan dengan bagian mana yang tertutup dan mana yang tidak tercakup.

2) Bagaimana fakta-fakta itu ditulis. Aspek ini berkaitan dengan penggunaan kata, kalimat, dan gambar untuk mendukung ide tersebut (Eriyanto, 2011).

Penelitian ini menggunakan analisis model framing Robert N. Entman. Model Entman menekankan proses seleksi dari berbagai aspek realitas sehingga bagian tertentu dari peristiwa itu lebih menonjol daripada aspek lain. Entman juga menyertakan penempatan informasi-informasi dalam konteks yang khas sehingga sisi tertentu mendapatkan alokasi lebih besar daripada sisi yang lain (Eriyanto, 2011). Menurut Entman dalam (Eriyanto, 2011) framing dalam berita dilakukan dengan empat cara, yaitu:

1. Pendefinisian masalah - Bagaimana suatu peristiwa/isu dilihat? Sebagai apa? Atau sebagai masalah apa?

2. Memperkirakan masalah atau sumber masalah - Peristiwa itu dilihat disebabkan oleh apa? Apa yang dianggap sebagai penyebab dari suatu masalah? Siapa (aktor) yang dianggap sebagai penyebab masalah?

3. Membuat keputusan moral - Nilai moral apa yang disajikan untuk menjelaskan masalah? Nilai moral apa yang dipakai untuk melegitimasi atau mendelegitimasi suatu tindakan?

4. Menekankan penyelesaian - Penyelesaian apa yang ditawarkan untuk mengatasi masalah/ isu? Jalan apa yang harus ditempuh untuk mengatasi masalah?

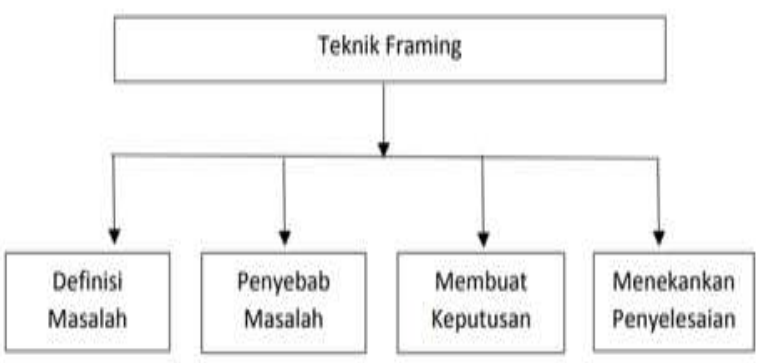

\section{Bagan I. Empat Cara Framming dalam Pemberitaan}

Menurut (Bungin, 2008), memaparkan bahwa format deskripsi kualitatif bertujuan untuk menggambarkan, meringkas, berbagai kondisi, situasi, atau fenomena realitas social dalam masyarakat yang menjadi objek penelitian dan berupaya menarik realitas itu ke permukaan sebagai suatu ciri, karakter, sifat model, tanda, atau gambaran tentang fenomena, situasi, ataupun fenomena tertentu.

\section{HASIL DAN PEMBAHASAN}

Dalam penelitian ini penulis melakukan analisis terhadap berita-berita di dua media online, yaitu: Kompas.com dan BBCIndonesia.com, dengan rincian berita sebagai berikut :

Tabel 1.

Sampel Berita tentang Penangkapan Mensos terkait korupsi Bansos Covid 19

\begin{tabular}{|c|c|c|}
\hline No & Judul & Media \\
\hline 1 & $\begin{array}{lr}\text { Juliari } & \text { Batubara Jadi } \\
\text { Tersangka, Total } & 4 \\
\text { Menteri di Era Jokowi } \\
\text { yang } & \text { Tersandung } \\
\text { Kasus } & \text { Dugaan } \\
\text { Korupsi } & \end{array}$ & $\begin{array}{c}\text { Kompas.com } \\
\text { (6 Desember } \\
\text { 2020) }\end{array}$ \\
\hline 2 & $\begin{array}{lr}\text { Mensos } & \text { Juliari } \\
\text { Batubara } & \text { jadi } \\
\text { tersangka } & \text { korupsi } \\
\text { bansos } & \text { Covid-19, } \\
\text { ancaman } & \text { hukuman } \\
\text { mati bakal menanti? }\end{array}$ & $\begin{array}{c}\text { BBCIndonesia } \\
\text { (6 Desember } \\
\text { 2020) }\end{array}$ \\
\hline
\end{tabular}

Sumber: Peneliti, 2021

Adapun objek penelitian yang penulis coba angkat adalah mengenai kasus korupsi dana Bansos Covid 19 dan penangkapan Mentri Sosial Juliari Batubara oleh KPK. Pembingkaian berita dilakukan 
dengan mengamati judul berita, foto yang disajikan, nara sumber beserta isi berita yang terkandung di dalamnya.

\section{Analisis Framing di Kompas.com}

Judul berita: "Juliari Batubara Jadi Tersangka, Total 4 Menteri di Era Jokowi yang Tersandung Kasus Dugaan Korupsi” di Kompas.com

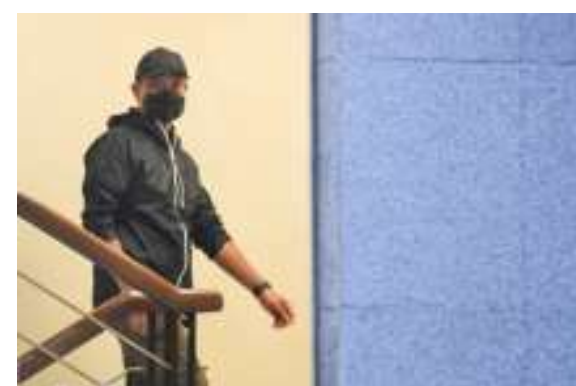

Sumber: Kompas.com

Gambar 3.1.

Menteri Sosial Juliari P Batubara tiba di Gedung KPK

Juliari Batubara terkait dugaan korupsi dana Bansos Covid 19. Kompas.com memberitakan ini pada 6 Desember 2020. Foto yang ditampilkan dalam berita tersebut adalah saat Juliari P Batubara selaku Mentri Sosial sedang berada di Gedung KPK. Secara umum, pembingkaian berita menunjukkan bagaimana Kompas.com mempersepsi keterlibatan Juliari Batubara selaku Mentri Sosial dan ditetapkan sebagai tersangka oleh KPK atas dugaan menerima suap terkait pengadaan bantuan sosial penanganan COVID-19 di Kementerian Sosial usai Operasi Tangkap Tangan (OTT) pejabat Kemensos. Analisis framing pemberitaan Kompas.com adalah sebagai berikut:

Define problem, terdapat dua define problem pada pemberitaan ini, yaitu:

1. Juliari Batubara selaku Mentri Sosial ditetapkan sebagai tersangka oleh Komisi Pemberantasan Korupsi (KPK) di kasus dugaan suap bantuan sosial penanganan pandemi Covid-19 untuk wilayah Jabodetabek di tahun 2020.

2. Define problem kedua yaitu 4 Menteri di Era Jokowi yang Tersandung Kasus Dugaan Korupsi. Penekanan Pendefinisian masalah dinyatakan dalam pernyataan Ketua KPK Firli Bahuri mengungkapkan, konstruksi kasus ini berawal dari pengadaan paket sembako sebagai bansos penanganan Covid19 dengan total 272 kontrak senilai Rp 5,9 triliun yang dilaksanakan selama dua periode dan setelah melalui pemeriksaan, akhirnya ditetapkan sebagai tersangka kasus korupsi Bansos penanganan Covid 19. Adapun Juliari disangka melanggar Pasal 12 huruf a atau Pasal 12 huruf b atau Pasal 11 Undang-Undang (UU) Pemberantasan Tindak Pidana Korupsi juncto Pasal 55 Ayat (1) ke-1 KUHP.

Diagnose Cause, sumber masalah dalam berita ini adalah munculnya statemen bahwa satu lagi menteri di era kepemimpinan Presiden Joko Widodo yang terjerat kasus dugaan korupsi yakni, Menteri Sosial Juliari P Batubara (JPB). Juliari menjadi menteri keempat yang tersandung kasus dugaan korupsi terhitung sejak periode pertama kepemimpinan Presiden Jokowi (2014-2019). Dua orang lainnya yakni eks Menteri Pemuda dan Olahraga (Menpora) Imam Nahrawi serta eks Menteri Sosial Idrus Marham, merupakan menteri Jokowi di Kabinet Kerja, yakni pada periode 2014-2019. Di periode kedua (2019-2024), menteri Jokowi yang terjerat yaitu Menteri Kelautan dan Perikanan Edhy Prabowo. Penangkapan Edhy tak berselang lama dari kasus yang menjerat Juliari. Keempat menteri tersebut berasal dari partai politik. Adapun Idrus merupakan kader Partai Golkar dan Imam merupakan kader Partai Kebangkitan Bangsa (PKB). Kemudian, Edhy adalah kader Partai Gerindra dan Juliari adalah politikus PDI Perjuangan. Ini memunculkan sebuah konstruksi media jika pada kepemimpinan Jokowi banyak sekali terjadi pelanggaran yang di lakukan oleh mentri pada jajaran era kepemimpinan Jokowi.

Make Moral Judgment adalah dengan adanya kejadian pada kasus dugaan suap dana Bansos yang di lakukan mentri sosial Juliari P Batubara ini menjadi sebuah kendala dalam upaya pencegahan penularan dan penyaluran bantuan kepada masyarakat yang terkena imbas covid 19 di Indonesia.

Treatment Recommendations, Juliari $\mathrm{P}$ Batubara telah ditetapkan sebagai tersangka oleh Komisi Pemberantasan Korupsi (KPK) di kasus dugaan suap bantuan sosial penanganan pandemi Covid-19 untuk wilayah Jabodetabek di tahun 2020. Penetapan tersangka ini merupakan tindak lanjut atas operasi tangkap tangan yang dilakukan KPK pada Jumat (5/12/2020) dini hari. Setelah pengumuman penetapan tersangka, KPK sempat meminta Juliari untuk menyerahkan diri. Juliari akhirnya tiba di Gedung KPK pada Minggu (6/12/2020), diharapkan dengan adanya pemberitaan mengenai penangkapan dan penyerahan diri tersangka akan membuat kasus semacam ini tidak akan terjadi lagi.

Setelah melalui beberapa analisa pada pemberitaan tersebut, maka berdasarkan temuan empat elemen framing di media Kompas.com, dapat disimpulkan bahwa media Kompas.com mengkonstruksi realitas tentang kasus dugaan korupsi dana Bansos Covid-19 melalui pendefinisian masalah yakni tertangkapnya Mentri Sosial era Presiden Joko Widodo yaitu Juliari P batubara dalam 
kasus korupsi dana bansos covid 19. Nilai moral yang ditampilkan oleh Kompas.com adalah pentingnya kesadaran terhadap semua pihak untuk tidak mencoba melalukan tindak korupsi terutama bantuan sosial bencana, karena dengan adanya kejadian pada kasus dugaan suap dana Bansos yang di lakukan mentri sosial Juliari P Batubara ini menjadikan sebuah kendala dalam upaya pencegahan penularan covid 19 di Indonesia.

Media bukanlah saluran yang bebas, media merupakan subjek yang mengkonstruksi atas realitas lengkap dengan pandangan, bias dan pemihaknya (Eriyanto, 2008). Dalam hal ini media Kompas.com memberikan ruang pada pemerintah dan Lembaga KPK dalam menyampaikan pendapat tentang salah satu aspek terbesar yang mempengaruhi pada upaya penanganan bencana dan kelancaran pemberian bantuan social kepada seluruh masyarakat Indonesia yang terdampak covid 19 sehingga dapat tepat sasaran .

Kompas.com dalam mengemas sebuah berita lebih mengedepankan urgensi pada pentingnya pemahaman bahwa tindak pidana korupsi dana bansos akan sangat merugikan semua pihak dan menghambat upaya penanganan bencana, serta melakukan framing melalui upaya KPK dan Pemerintah dalam menjalankan upaya pemulihan terkait Covid 19.

\section{Analisis Framing di Media BBCIndonesia.com}

Judul berita: Mensos Juliari Batubara jadi tersangka korupsi bansos Covid-19, ancaman hukuman mati bakal menanti?

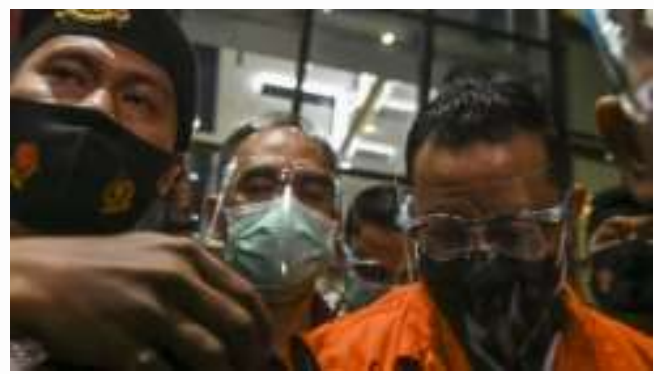

Sumber: BBCIndonesia.com

Gambar 3.2.

Mensos Juliari P Batubara berjalan menuju mobil tahanan usai menjalani pemeriksaan di Gedung

(KPK), Jakarta,

Gambar 3.2 diatas adalah pemberitaan kedua mengenai diputuskannya Juliari Batubara selaku mensos menjadi tersangka korupsi bansos covid 19. Media online BBCIndonesia.com memuat berita ini pada 6 Desember 2021. Foto yang ditampilkan dalam berita tersebut adalah Menteri Sosial Juliari P Batubara berjalan menuju mobil tahanan usai menjalani pemeriksaan di Gedung Komisi Pemberantasan Korupsi (KPK), Jakarta,. Secara umum, pembingkaian berita menunjukkan bagaimana BBCIndonesia.com mempersepsi jika Bansos sangat rawan untuk di korupsi sehingga Juliari P Batubara dinyatakan sebagai tersangka dalam kasus korupsi bansos covid 19 dan dapat terancam dengan hukuman mati. Analisis framing pemberitaan BBCIndonesia.com adalah sebagai berikut:

Define Problem, pada pemberitaan ini terdapat dua define problem, yaitu: Ketua KPK, Firli Bahuri, menyatakan bahwa keterlibatan mensos dalam kasus korupsi covid 19 dan menduga Juliari Peter Batubara menerima Rp17 miliar dari korupsi bansos sembako yang ditujukan untuk keluarga miskin yang terdampak akibat wabah virus corona. Define problem yang kedua adalah kasus korupsi dan bansos dapat di jatuhi hukuman mati, ini dipertegas oleh Menteri Koordinator Bidang Politik Hukum dan Keamanan, Mahfud Md, mengatakan, pejabat pusat dan daerah yang melakukan tindak korupsi berkaitan dengan anggaran bencana Covid-19 terancam hukuman mati.

"Saya ingatkan, menurut UU Tindak Pidana Korupsi (Tipikor), diancam dengan paling tinggi seumur hidup atau 20 tahun penjara. Namun, dalam keadaan bencana seperti saat Covid-19 ini, maka ancaman hukuman mati ini diberlakukan berdasarkan UU yang berlaku,"

tegas Mahfud dalam Rapat Koordinasi Nasional Pengawasan Intern Pemerintah Tahun 2020, 15 Juni lalu. Penekanan pendefinisian masalah dinyatakan dalam bentuk pernyataan berikut ini: Ketua KPK Firli Bahuri pada Agustus lalu menuturkan, "kondisi pandemi Covid-19 masuk atau memenuhi unsur 'dalam keadaan tertentu' sesuai ayat 2 pasal 2 Undang-Undang Nomor 20 Tahun 2001 tentang Pemberantasan Tindak Pidana Korupsi. Sehingga, hukuman mati layak menjadi hukuman bagi pelaku koruptor bansos." Hal ini menjadi dasar penekanan kata "ancaman hukuman mati bakal menanti" menjadi penting untuk muncul dalam judul berita sebagai langkah penekanan keseriusan pemerintah dalam menanggulangi kasus korupsi bansos.

Diagnose Cause, sumber masalah dalam berita ini adalah terungkapnya dugaan korupsi dana bansos, hal ini dipertegas dalam konferensi pers, Ketua KPK, Firli Bahuri, menduga Juliari Peter Batubara menerima Rp17 miliar dari korupsi bansos sembako yang ditujukan untuk keluarga miskin yang terdampak akibat wabah virus corona. KPK menduga uang tersebut digunakan untuk keperluan pribadi.

Make Moral Judgment, dengan terjadinya kasus korupsi dana bansos yang dilakukan mensos juliari batubara mengakibatkan terjadi kerugian negara dan menghambat penerimaan bantuan terhadap masyarakat yang terdampak kasus covid 19 ini, Sebelumnya, Peneliti Pusat Kajian Anti Korupsi Universitas Gadjah Mada (Pukat UGM), Hanifah Febriani, mengungkapkan pemberian dana bansos di situasi bencana rentan membuka celah korupsi. 
Hanifah melanjutkan, secara umum modus korupsi yang muncul dalam penyaluran dana bansos, yaitu mengurangi jatah penerima atau bahkan ada yang tidak menerima bansos sama sekali.

Treatment Recommendations, solusi yang dtawarkan dalam berita ini adalah pemerintah akan menindak tegas pelaku tindak korupsi dana bansos dan akan menerapkan hukuman maksimal yaitu hukuman mati. Juliari Batubara menyerahkan diri ke KPK pada Minggu (06/12) dini hari setelah ditetapkan sebagai tersangka kasus dugaan korupsi bantuan sosial (bansos). Mengenakan jaket, topi dan masker warna hitam, Juliari tiba di KPK pada Minggu (06/12) pukul 02.45 WIB, hampir satu jam setelah KPK menggelar konferensi pers penetapan tersangka dirinya dan sejumlah pejabat Kemensos serta pihak swasta. Penetapan tersangka Juliari merupakan perkembangan operasi tangkap tangan pada Sabtu $(05 / 12)$ lalu terkait dugaan korupsi bansos untuk wileteayah Jabodetabek tahun 2020 di Kementerian Sosial.

Judul yang diangkat BBCIndonesia "Mensos Juliari Batubara jadi tersangka korupsi bansos Covid-19, ancaman hukuman mati bakal menanti?" menunjukkan penekanan pada keseriusan pemerintah melalui Lembaga KPK untuk menuntaskan dan membongkar kasus korupsi dana bantuan social yang di anggap sangat melukai perasaan seluruh rakyat Indonesia, dimana hal tersebut justru dilakukan saat bangsa sedang berjuang dalam mengatasi masalah pandemi yang telah meluluh lantakkan berbagai sector dan kemanusiaan. BBCIndonesia juga memberikan pemberitaan berupa penegasan pemerintah dalam memaksimalkan hukuman berupa hukuman mati bagi semua pelaku korupsi dana bantuan social sehingga, hukuman mati layak menjadi hukuman bagi pelaku koruptor bansos. Sehingga diharapkan tidak akan ada lagi celah yang dapat membuka jalan untuk melakukan korupsi dana bantuan social covid 19 .

\section{KESIMPULAN}

Setelah melalui beberapa analisa pada pemberitaan tersebut, maka berdasarkan hasil analisa framing dalam penelitian ini, maka sangat jelas terlihat bahwa peran media tidak sebatas sebagai penyampai informasi, perkembangan zaman menuntut media menjalankan peran 'watch dog' atau anjing penjaga serta mengontrol bagi pemerintah dan Lembaga terkait atas dalam merumuskan setiap kebijakan untuk kepentingan masyarakat. Hasil penelitian menunjukan bahwa media Kompas.com dan BBCIndonesia.com memberikan ruang informasi dan klarifikasi bagi pemerintah dan Lembaga KPK untuk melakukan segala upaya penertiban dan penganggulangan masalah korupsi dana bansos covid 19.

Hasil penelitian ini menunjukan beberapa point penting; Pertama, define problem yakni terungkapnya kasus korupsi bansos dana bantuan social yang dapat merugikan negara dan masyarakat sehingga menghalangi tujuan pemerintah dalam mengatasi dan menanggulangi kasus covid 19. Kedua diagnose cause yaitu Juliari P Batubara selaku Mentri Sosial telah terbukti melakukan korupsi dana bansos covid 19. Ketiga, make moral judgment menguatkan pentingnya kesadaran terhadap semua pihak untuk tidak mencoba melalukan tindak korupsi terutama bantuan sosial bencana, dimana dengan terjadinya kasus korupsi dana bansos yang dilakukan mesos juliari batubara mengakibatkan terjadi kerugian negara dan menghambat penerimaan bantuan terhadap masyarakat yang terdampak kasus covid 19 ini, Keempat, treatment recommendations adalah pemerintah akan menindak tegas pelaku tindak korupsi dana bansos dan akan menerapkan hukuman maksimal yaitu hukuman mati. Sehingga diharapkan tidak akan ada lagi celah yang dapat membuka jalan untuk melalukan korupsi dana bantuan social covid 19.

Dari semua pembahasan diatas menunjukan bagaimana media mengkonstruksi makna dalam setiap elemen-elemen beritanya. Media memiliki kekuasaan dalam menentukan sudut pandang atas segala kebijakan pemerintah, dalam artian media sebagai mengkritik dengan cara yang berbeda-beda. Melalui temuan penelitian ini diharapkan media mampu membantu pemerintah sebagai perpanjangan tangan bukan saja menyampaikan pesan-pesan yang kontroversial tetapi juga konten berita yang positif sehingga mampu berjalan searah dengan pemerintah dalam upaya menghentikan, meringankan dan menanggulangi kasus Covid 19.

\section{DAFTAR PUSTAKA}

\section{Buku dan Jurnal}

Anwar, A. (2011). Komunikasi Politik. Yogyakarta: Graha Ilmu.

Bungin, B. (2008). Konstruksi Massa, Sosial Media. Jakarta: Kencana Prenada Media Group.

Elvras Jaya, D. (2019). Analisis framing pemberitaan kasus korupsi e-ktp oleh setya novanto di cnnindonesia.com dan viva.co.id. Jurnal Ilmiah, 4(3). Retrieved from www.jim.unsyiah.ac.id/fisip

Entman, R. . (2007). Framing Bias: Media in the Distribution of Power. Journal of Communication, 57(1), 163-173. Retrieved from

https://onlinelibrary.wiley.com/doi/abs/10.111 1/j.1460-2466.2006.00336.x

Eriyanto. (2008). Konstruksi. Ideologi. dan Politik media. Yogyakarta: LKis.

Eriyanto. (2011). Analisis Framing”: Konstruksi Ideologi, dan Politik Media. Yogyakarta: cLKis.

Ibrahim, I. S. (2007). Budaya Populer Sebagai Komunikasi. Yogyakarta: Jalasutra. 
Kriyantono, R. (2016). Teknik Praktis Riset Komunikasi. Jakarta.

Malik, R. K. (2019). POLEMIK HIJAB MIFTAHUL JANNAH DI ASIAN PARA GAMES 2018 Kalijaga Journal of Communication, 1(1), 2361.

Puji, S. (2016). Konstruksi Sosial Media Massa Puji Santoso Dosen Komunikasi Fakultas Ilmu Sosial dan Ilmu Politik Universitas Muhammadiyah Sumatera Utara. Al-Balagh, $1(1), 34$.

Sovianti, R. (2019). Analisis Framing: Pemberitaan Penangkapan Kasus Korupsi E-KTP Setya Novanto di Media Daring Detik.Com dan Kompas.Com. Jurnal Komunikasi, Masyarakat Dan Keamanan (KOMASKAM), 1(1), 47-61.

Sugiyono. (2017). Metode Penelitian Kuantitatif, Kualitatif, dan R\&D. Bandung.

Wijanarko, Y. A. (2014). Analisis Framing Deklarasi Pencapresan Jokowi di Media Massa. JURNAL KOMUNIKASI YUDHI AGUNG. Retrieved from

https://www.jurnalkommas.com/docs/JURNA L KOMUNIKASI YUDHI AGUNG D1210087.pdf

Yeni, Selviera, Chelsy, Y. (2018). No Title. Konstruksi Realitas Berita Korupsi Mantan Bupati Bengkalis Herliyan, 5(1). Retrieved from

https://jom.unri.ac.id/index.php/JOMFSIP/arti cle/view/17265

\section{Website}

https://nasional.kompas.com/read/2020/12/06/0 3534351/mensos-juliari-batubara-tiba-digedung-kpk (diakses pada 22 Januari 2021 pukul 20.48)

https://nasional.kompas.com/read/2021/01/14/0 $\underline{8452811 / \text { kasus-suap-juliari-batubara-dirjen- }}$ kemensos-diperiksa-kpk diakses pada 22 Januari 2021 pukul 20.56)

https://nasional.kompas.com/read/2020/12/06/0 9231651/juliari-batubara-jadi-tersangka-total-4menteri-di-era-jokowi-yang?page $=$ all diakses pada 22 Januari 2021 pukul 20.56)

https://www.bbc.com/indonesia/indonesia55204360 diakses pada 24 Januari 2021 pukul $\underline{13.45)}$

\section{PROFILE PENULIS}

Intan Leliana S.Sos.I.MM, Lahir Jakarta, 21 Desember 1986. Saat ini saya adalah staf Akademik dan Dosen Universitas Bina Sarana Informatika, Program Studi Hubungan Masyarakat, yang beralamat Alamat BSI Pemuda, Jalan Kayu Jati 5, Rawamangun, Jakarta Timur. Saat ini sedang kuliah untuk program Magister di Universitas Sahid Jakarta (Sekolah Pascasarjana) dengan Program Studi Ilmu Komunikasi.

Herry S.Sn.MM, Lahir Singkawang, 27 Agustus 1974. Saat ini saya adalah Dosen Universitas Bina Sarana Informatika, Program Studi Periklanan, yang beralamat Alamat BSI Pemuda, Jalan Kayu Jati 5, Rawamangun, Jakarta Timur. Saat ini sedang kuliah untuk program Magister di Universitas Sahid Jakarta (Sekolah Pascasarjana) dengan Program Studi Ilmu Komunikasi.

Panji Suratriadi S.Sos.MM, Lahir Jakarta, 1 Desember 1971. Saat ini saya adalah Dosen Universitas Bina Sarana Informatika, Program Studi Hubungan Masyarakat, yang beralamat Alamat BSI Pemuda, Jalan Kayu Jati 5, Rawamangun, Jakarta Timur. Saat ini sedang kuliah untuk program Magister di Universitas Sahid Jakarta (Sekolah Pascasarjana) dengan Program Studi Ilmu Komunikasi.

Edward Enrieco , SE., MM. Lahir Pontianak, 25 Mei 1971. Bekerja sebagai Dosen mata kuliah Fotografi \& Videografi Universitas Bina Sarana Informatika program studi Penyiaran dan sebagai mahasiswa prodi Magister Ilmu Komunikasi di Pasca Sarjana Universitas Sahid. 